\title{
Understanding Visitor Motivations at Jimmy Carter National Historic Site: A Principal Components Approach
}

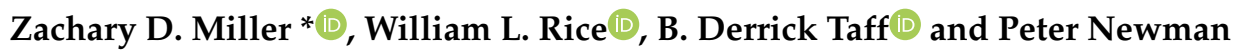 \\ Department of Recreation, Park, and Tourism Management, The Pennsylvania State University, University Park, \\ PA 16802, USA; wlr5053@psu.edu (W.L.R.); bdt3@psu.edu (B.D.T.); pbn3@psu.edu (P.N.) \\ * Correspondence: zdm9@psu.edu
}

Received: 23 October 2018; Accepted: 12 November 2018; Published: 14 November 2018

check for updates

\begin{abstract}
National park sites draw tourism all across the United States. Although large natural parks see much attention, most national park units are actually designed to protect and interpret unique cultural and historic resources. As an example of this, the National Park Service administers numerous presidential historic sites. However, we know very little about the people who visit them. Understanding visitor motivations to presidential historic sites can help to provide for better visitor experiences of presidential resources. This research uses intercept surveys at the Jimmy Carter National Historic Site in Plains, Georgia, to gain an understanding of visitor motivations. From the results, seven motivation types are identified. The information in this article can be used to better understand public values related to presidential resources, and to help the managers of these resources to improve on-site experiences by addressing visitor motivations.
\end{abstract}

Keywords: national parks; presidents; visitor use; visitor experience; historic sites

\section{Introduction}

The National Park Service (NPS) is charged with allowing the public enjoyment of cultural, natural, and historic resources while also leaving the same resources unimpaired for future generations. This includes a variety of historic sites related to numerous presidents of the United States. A critical component to providing public enjoyment of presidential historic resources is understanding visitor motivations for experiencing these unique protected areas [1]. The NPS manages over 400 sites, 78 of which are National Historic Sites (NHS) [2]. Although the number of NHS managed by the NPS is greater than the number of national parks (59 national parks) [2], very little is known about visitors to presidential historic sites, their experiences, and their motivations. The purpose of this research is to describe visitor motivations at the Jimmy Carter National Historic Site in Plains, Georgia to better understand and manage visitor experiences at presidential historic sites in the NPS.

Visitors to national parks and historic sites arrive in those location with motivations for engaging in activities. Motivations are often called recreation experience preferences (REPs) [3,4]. As opposed to focusing on activity, REPs focus on the psychophysiological aspects of an experience, such as physical exercise, learning, and family togetherness [4]. These REPs help to explain why visitors are coming to a location, and they also explain the variation in the outcomes of visitors participating in the same activity. These motivations are critical for managers to understand, as they provide context for visitor behavior and assist managers in providing quality visitor experiences [4]. 


\section{Study Location and Background}

Jimmy Carter National Historic Site (JICA) is located in Plains, Georgia (Figure 1). As the name suggests, JICA is designated as a NHS to honor and interpret the life, presidency, and other public services of Jimmy Carter, who served as the 39th President of the United States (1977-1981). The site is unique among the other 41 sites preserved by the NPS related to Presidential history, in that it includes the home of a living former President [5]. Along with the residence of President and Mrs. Carter, the NHS contains three other primary points of interests: Plains High School Museum and Visitor Center, Plains Depot, and the Carter Boyhood Home. Each site interprets unique periods of President Carter's life [6].

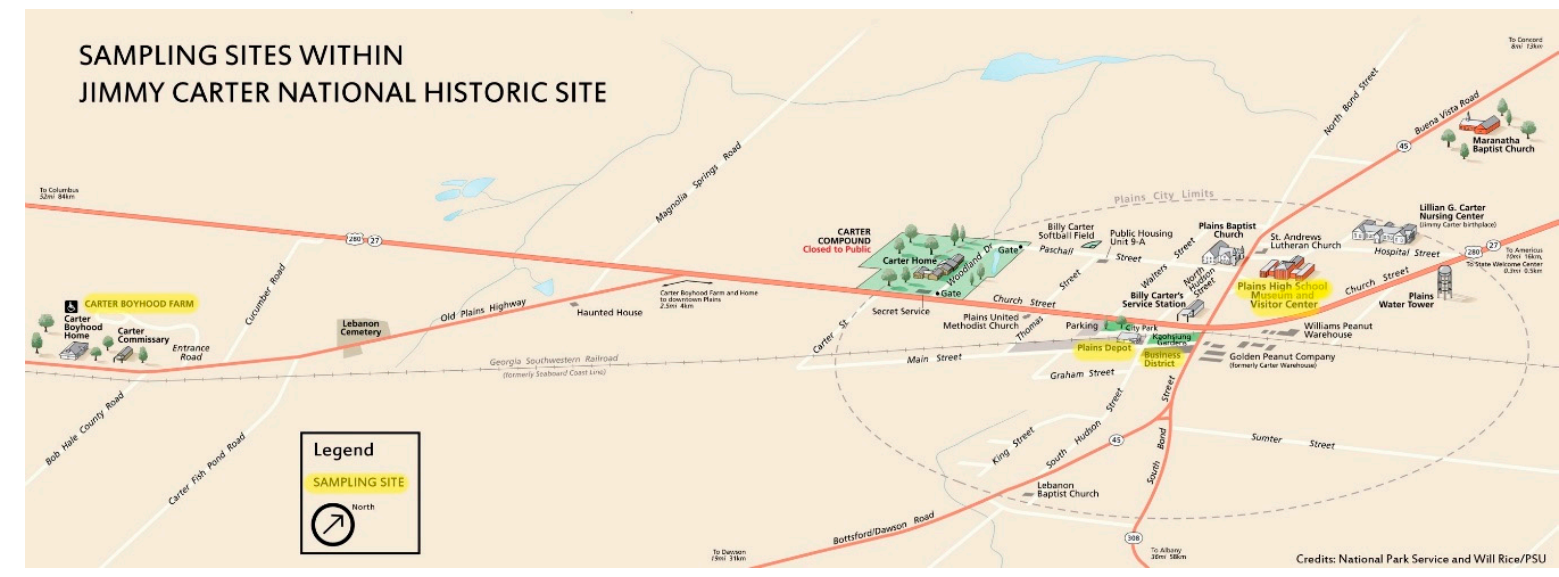

Figure 1. Map and sampling locations at Jimmy Carter National Historic Site [7].

Plains High School serves as the headquarters of the NHS unit, and contains a museum that displays the dramatic arch of President Carter's life-from Georgia farmboy to Nobel Prize-winning humanitarian. It also hosts exhibits that are specific to the accomplishments of First Lady Rosalynn Carter, the impactful life of schoolteacher Julia Coleman, and life in Plains, Georgia. The school auditorium screens a biographical video about President Carter upon request, and an Eastern National bookstore is located near the primary entrance [8].

In downtown Plains, the NPS manages the Plains Train Depot that served as President Carter's campaign headquarters during his 1976 presidential bid. Accordingly, the site contains a small museum dedicated to Carter's campaign and the crucial involvement of the Plains community in his victory. Just outside of town, in the village of Archery, the NPS has preserved the boyhood home of the President Carter [9]. A self-guided walking tour loops visitors through various indoor and outdoor interpretive exhibits including, in spatial order: active goat and chicken pens, Lillian Carter's pecan grove, the Carter house, James Earl Carter Sr.'s tennis court and commissary, an active vegetable garden, a blacksmith shed, the Clark house (home to long-time sharecroppers Jack and Rachel Clark), barn, and active horse pastures. Both the Plains Train Depot and Boyhood Farm are easily accessed by periodic Presidential train tours. All sites have dedicated parking lots [7].

Though not all are managed by JICA, the Jimmy Carter National Preservation District contains more than twenty historically relevant structures, many of which are popular points of interest for visitors [10]. A selection of these include: the commercial businesses on Main Street, Billy Carter's Service Station, and Maranatha Baptist Church—all of which remain open to the public [11]. Maranatha Baptist Church is also the site of President and Mrs. Carter's current place of worship, and where President Carter continues to lead public Sunday school lessons. These regularly scheduled teachings are a considerable draw for visitors to the NHS [8].

Though Southwest Georgia is characterized by its rural nature, the greater Plains area contains other attractions and accommodations for historically inclined tourists [12]. Eleven miles east of Plains sits the larger city of Americus, GA, providing accommodations to tourists [8]. Approximately 
20 miles northeast of Plains, the NPS manages and preserves Andersonville National Historic Site, and its National Prisoner of War Museum, and further to the northeast, in Macon, Ocmulgee National Monument preserves Mississippian American Indian mounds [13].

\section{Methods}

We conducted visitor intercept surveys onsite at JICA to answer a single research question: What are visitors' motivations for visiting the Jimmy Carter National Historic Site?

\subsection{Sample}

In April and May of 2017, visitors to JICA were systematically sampled in multiple locations, including Plains High School Visitor Center, Downtown Plains, Plains Train Depot, and the Boyhood Farm (Figure 1). The majority of respondents (67\%) completed the survey at the Plains High School Visitor Center. The Train Depot and the historic downtown were sampled in conjunction with the arrival of trains that brought school groups and other visitors to the national park. Visitors younger than 18 years of age were excluded from the research. Only one person per group was asked to participate in the research. To prevent selection bias, the person with the most recent birthday (not date of birth) that was over 18 years of age was asked to complete the survey. Out of 180 groups intercepted, 119 individuals agreed to complete the survey (response rate $=66 \%$ ). Based off a population size of 60,735 (visitation in 2017), we estimate the margin of error to be $\pm 8.97 \%$ with a confidence level of $95 \%$ [14].

\subsection{Data Instrument}

A questionnaire was presented to respondents on an electronic tablet. This included a variety of trip-planning questions that were of interest to JICA managers, but that are not included in this manuscript. Motivation measures were developed through discussions with JICA managers and other NPS employees, as well as previous qualitative research collected during the planning process. In total, 30 different motivation items were developed (Table 1). Visitor responses to the motivation items were measured on a scale from 1 to 5 , where 1 = not at all important, 2 = slightly important, $3=$ moderately important, $4=$ very important, and $5=$ extremely important. Visitors were also given an option to select "not relevant" for each item. If "not relevant" was selected, the case was deleted listwise. The survey also included basic demographic questions. The survey instrument was approved by the Federal Office of Management and Budget (OMB) and a university institutional review board (IRB) for use at JICA.

\subsection{Analysis}

A principal components analysis (PCA) was used to examine the underlying structure of the motivation items. As a data-reduction technique, PCA reduces the 30 motivation variables into a smaller set of "latent" variables, called components, which represent an underlying relationship. Bartlett's test of sphericity and the Kaiser-Meyer-Olkin (KMO) statistic are used to assess if PCA is an appropriate technique for a data set. Bartlett's test of sphericity should be significant $(p<0.05)$, and KMO should be $>0.50$. Standard practice in PCA is to extract components with eigenvalues $>1$, which we adhered to. A minimum loading of $\geq 0.40$ is considered as the threshold for a measured item to belong to an underlying component [15]. Cross-loading (e.g., when an item belongs to more than one component) was not allowed, and any items that were cross-loaded were eliminated. To assess of the reliability of the items forming a component, Cronbach's $\alpha$ is used, with $\alpha>0.65$ being considered sufficient [15]. Once components were identified through both the PCA and Cronbach's $\alpha$, the items were averaged into a single component score. 


\section{Results}

\subsection{Sample Characteristics}

The vast majority of visitors to JICA were first-time visitors $(89 \%)$. The median respondent age was 63 years, with a minimum of 18 years and a maximum of 92 years. Sex was nearly evenly split, with $52 \%$ of respondents identifying as female. The majority (55\%) of visitors were in groups of two or more people, and about $89 \%$ of visitors were there without children. Ninety-nine percent of visitors were from the United States of America, and over $94 \%$ of visitors identified as White. The average duration of JICA visitors was just under three hours.

\subsection{Motivations for Visiting Jimmy Carter National Historic Site}

The assumptions for the PCA were satisfied: Bartlett's test of sphericity was $p<0.001$ and KMO was 0.879 . Overall, seven components were extracted from the 30 items and collectively explained over $72 \%$ of the original variance (Table 1 ). Examining the motivation items that loaded on to each component, these components were named: (1) reflective experience, (2) escape from everyday life, (3) social bonding, (4) southern and rural history, (5) presidential life and contributions, and (6) Jimmy Carter. A seventh factor was represented by a single item, represented as the original item "to visit all presidential historic sites" (see Table 1).

Table 1. Visitor motivations at Jimmy Carter National Historic Site. ${ }^{1}$

\begin{tabular}{|c|c|c|c|}
\hline Component & Variables & Factor Loading & Mean $(s d)$ \\
\hline & $\begin{array}{c}\text { Reflective experience } \\
\qquad \alpha=0.93\end{array}$ & & $2.97(0.92)$ \\
\hline & To experience tranquility and contemplativeness in nature. & 0.791 & 3.05 (1.05) \\
\hline & To experience the diversity of the natural world. & 0.800 & $2.93(1.06)$ \\
\hline & To experience solitude. & 0.853 & $2.71(1.01)$ \\
\hline & To experience a feeling of calmness and peace. & 0.786 & $2.98(1.06)$ \\
\hline & To think about my personal values. & 0.638 & $3.15(1.04)$ \\
\hline & $\begin{array}{l}\text { Escape from everyday life } \\
\qquad \alpha=0.88\end{array}$ & & $2.98(0.88)$ \\
\hline & To give my mind a rest. & 0.745 & $3.00(1.06)$ \\
\hline & To get away from the usual demands of life. & 0.777 & $3.27(1.05)$ \\
\hline & To get away from the noise back home. & 0.869 & $2.79(1.07)$ \\
\hline & To escape from answering emails, texts, or phone calls. & 0.712 & $2.66(1.09)$ \\
\hline & To experience a sense of adventure. & 0.524 & $3.16(1.03)$ \\
\hline & $\begin{array}{c}\text { Social bonding } \\
\alpha=0.90\end{array}$ & & $3.25(1.06)$ \\
\hline & To spend time with friends/family. & 0.875 & $3.39(1.17)$ \\
\hline & To bring my family closer together. & 0.832 & $2.99(1.17)$ \\
\hline & To share this place with my family/friends & 0.818 & $3.37(1.15)$ \\
\hline & $\begin{array}{l}\text { Southern and rural history } \\
\qquad \alpha=0.77\end{array}$ & & $3.39(0.73)$ \\
\hline & To learn about the history and cultural significance of the area. & 0.649 & $3.94(0.91)$ \\
\hline & To learn about the community and environment of Plains, GA. & 0.668 & $3.32(0.91)$ \\
\hline & To experience historic southern culture & 0.625 & $3.32(0.99)$ \\
\hline & To experience historic farm life. & 0.650 & $2.96(0.97)$ \\
\hline
\end{tabular}


Table 1. Cont.

\begin{tabular}{|c|c|c|c|}
\hline Component & Variables & Factor Loading & Mean $(s d)$ \\
\hline & $\begin{array}{l}\text { Presidential life and contributions } \\
\qquad \alpha=0.68\end{array}$ & & $2.96(0.76)$ \\
\hline & To learn about Jimmy Carter's military service. & 0.778 & $2.88(1.19)$ \\
\hline & To learn how southern education shaped history. & 0.523 & $3.03(1.14)$ \\
\hline & To learn about past presidents. & 0.651 & $2.95(1.40)$ \\
\hline & $\begin{array}{c}\text { Jimmy Carter } \\
\alpha=0.67\end{array}$ & & $4.14(0.69)$ \\
\hline & To learn about the life and presidency of Jimmy Carter. & 0.747 & $4.45(0.79)$ \\
\hline & To learn about Jimmy Carter's values. & 0.786 & $4.20(1.07)$ \\
\hline & To potentially see or meet Jimmy Carter. & 0.610 & $3.77(1.47)$ \\
\hline \multirow[t]{9}{*}{$\begin{array}{c}\text { Single item } \\
\text { measure }\end{array}$} & & & - \\
\hline & To visit all presidential historic sites (including this one). & 0.746 & 3.35 (1.39) \\
\hline & Items excluded from analysis for cross-loading & & - \\
\hline & To learn about the civil rights movement. & - & $3.25(0.97)$ \\
\hline & To learn about historic agricultural practices. & - & $2.70(0.98)$ \\
\hline & To view the scenic beauty. & - & $3.26(0.96)$ \\
\hline & To experience a positive change in mood and emotion. & - & $3.10(1.03)$ \\
\hline & To get some exercise. & - & $2.91(1.03)$ \\
\hline & To improve my physical health. & - & $2.61(1.04)$ \\
\hline
\end{tabular}

${ }^{1}$ All variables measured on a 5-point scale where $1=$ not at all important and $5=$ extremely important.

The seven motivation components varied in their importance to JICA visitors (Figure 2). Overall, the top three motivation components for visiting JICA were Jimmy Carter, southern and rural history, and to visit all presidential historic sites. The three least important motivation components were escape from everyday life, reflective experience, and presidential life and contributions.

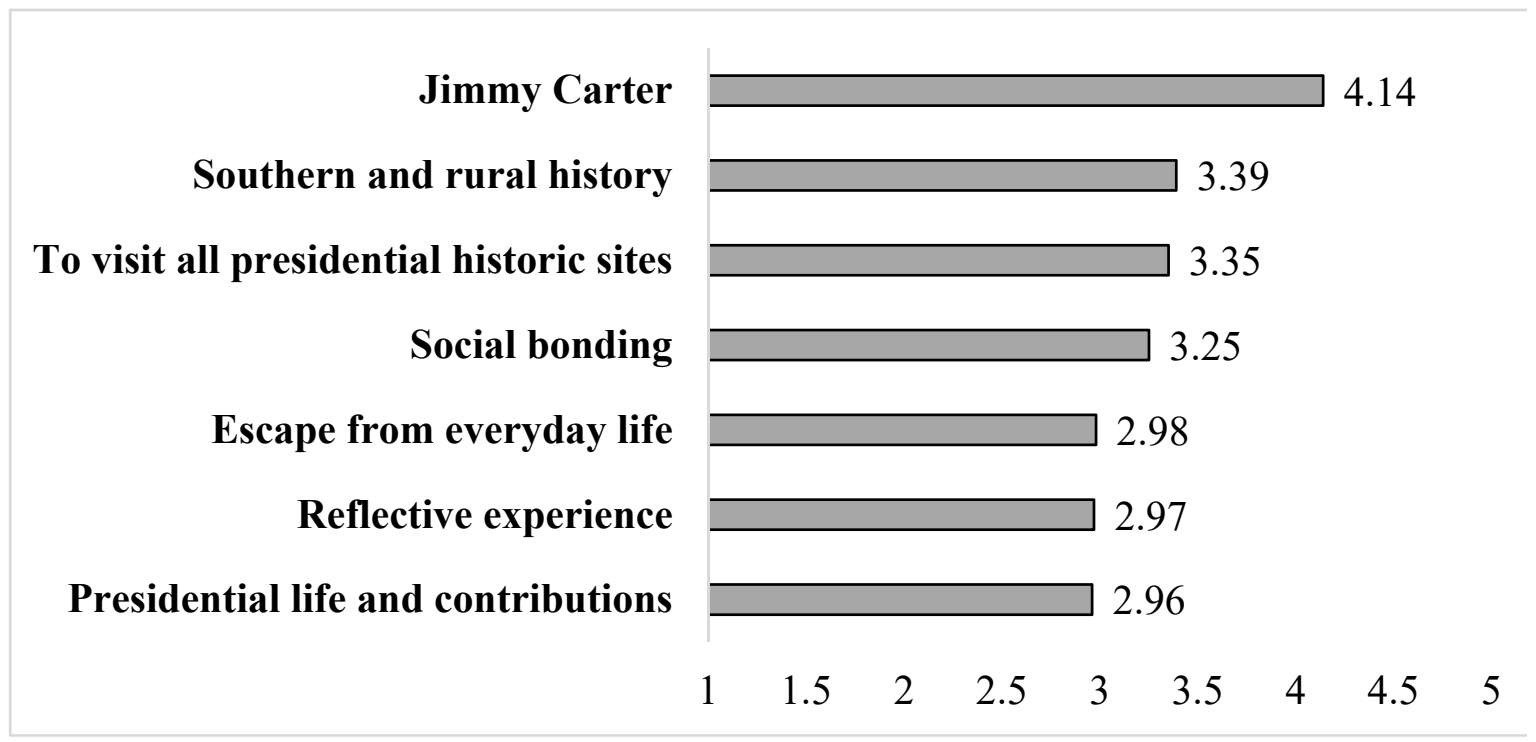

Figure 2. Comparison of motivation components for visiting Jimmy Carter National Historic Site. Items were measured on a 5 -point scale where $1=$ not at all important and $5=$ extremely important. 


\section{Discussion}

The purpose of this study was to identify visitor motivations at JICA. In this process, we begin to understand the unique value of historic presidential resources at JICA. Using onsite visitor intercept surveys to collect data, this research reveals that visitors have seven main reasons for visiting JICA (Table 1; Figure 2). Collectively, this information can help to inform the management of JICA, and possibly of other presidential historic sites, in a variety of ways.

For JICA specifically, managers can improve and plan for visitor experiences from these findings. For instance, it is clear that visitors are most motivated by information related specifically to Jimmy Carter, including his presidency and his values. Surprisingly, visitors were least motivated by "presidential life and contributions", including "learning about past presidents". However, visitors also found motivations that were unrelated to information about presidents as important, including southern and rural history, and social bonding. Using this information, managers can develop indicators of quality visitor experiences. In the field of visitor use management, the indicators are measurable and manageable components of the visitor experience, that serve as a proxy for management objectives [1]. By understanding how the visitor experience relates to these indicators of quality, managers at JICA can improve visitor satisfaction by providing opportunities that represent the most important components of the experience.

Although other sites may differ in setting, resources, and visitor demographics, this research may also be useful for thinking about the visitor experience at other presidential historic sites in the NPS. For instance, staying relevant is of particular interest to presidential historic sites in the NPS. Of the eight sites related to presidents of the latter half of the 20th century-Harry S. Truman NHS, Eisenhower NHS, John Fitzgerald Kennedy NHS, Lyndon Baines Johnson Memorial Grove on the Potomac, Lyndon B Johnson NHS, Jimmy Carter NHS, President William Jefferson Clinton Birthplace Home NHS, and The White House and President's Park—only half saw increased visitation from 2007 to 2017. During that same period, overall visitation to National Historic Sites and National Historic Parks increased over 20 percent [16]. As noted by Jager and Sanche and Oppegaard and Grigar [17,18], if national historic sites are to remain relevant in a changing social landscape, historians and managers must actively adapt to an increasingly urbanized, technologically inclined, and active population. This includes understanding visitor motivations, and helping to facilitate those desired experiences.

There are several notable limitations as well as future avenues for inquiry from this research. Due to the relatively low visitor use at JICA, the sample size was quite small $(n=119)$, and future research is needed to increase the certainty of these results. Increasing the sample size may also provide deeper insights into visitor motivations, such as a clustering of visitors into motivation typologies. Additionally, the population was rather homogenous, and populations at other presidential historic sites may be more diverse. The importance of some of the motivation components may be related to the homogenous sample at JICA, or possibly the physical characteristics of the setting (e.g., "view the scenic beauty"). Additional visitor experience research at presidential historic sites can help to overcome these limitations and to provide new insights.

Author Contributions: Z.D.M. provided writing, analysis, and conceptualization. W.L.R. provided writing, data collection, and conceptualization. B.D.T. and P.N. both provided writing and conceptualization.

Funding: This research was funded by the National Park Service.

Conflicts of Interest: The authors declare there are no conflict of interest.

\section{References}

1. Manning, R.E. Studies in Outdoor Recreation: Search and Research for Satisfaction; Oregon State University Press: Corvallis, OR, USA, 2011.

2. NPS. National Park System. Available online: https://www.nps.gov/aboutus/upload/Site-Designations01-13-17.pdf (accessed on 13 November 2018). 
3. Driver, B. Master List of Items for Recreation Experience Preference Scales and Domains; Rocky Mountain Forest and Range Experiment Station; USDA Forest Service: Fort Collins, CO, USA, 1983.

4. Manfredo, M.J.; Driver, B.L.; Tarrant, M.A. Measuring leisure motivation: A meta-analysis of the recreation experience preference scales. J. Leis. Res. 1996, 28, 188-213. [CrossRef]

5. NPS. American Presidents: List of Sites. Available online: https://www.nps.gov/nr/travel/presidents/list_ of_sites.html (accessed on 13 November 2018).

6. NPS. Foundation Document: Jimmy Carter National Historic Site: Georgia; Department of Interior: Atlanta, GA, USA, 2013.

7. NPS. Jimmy Carter National Historic Site, Georgia. Available online: https://www.loc.gov/item/ 2004626064/ (accessed on 13 November 2018).

8. Fodor's. Fodor's the Carolinas and Georgia; Random House: New York, NY, USA, 2015.

9. Kaiser, H.H. The National Park Architecture Sourcebook, 1st ed.; Princeton Architectural Press: New York, NY, USA, 2008.

10. Historic American Buildings Survey. Jimmy Carter National Historic Site and Preservation District, Plains, Sumter County, GA; Georgia Plains Sumter County. 1993. Available online: https:/ /www.loc.gov/item/ ga0605/ (accessed on 13 November 2018).

11. O'Brien, W.P. Special History Study: Jimmy Carter National Historic Site and Preservation District-Georgia; Department of Interior: Denver, CO, USA, 1991.

12. Carter, J. An Hour Before Daylight: Memoirs of a Rural Boyhood; Simon and Schuster: New York, NY, USA, 2001.

13. NPS. The National Parks: Lesser-Known Areas, U.S. Department of the Interior: Washington, DC, USA, 1985.

14. NPS. Recreation Visits by Month: Jimmy Carter National Historic Site. Available online: https: / irma.nps.gov/Stats/SSRSReports /Park\%20Specific\%20Reports/Recreation\%20Visitors\% 20By\%20Month\%20(1979\%20-\%20Last\%20Calendar\%20Year)?Park=JICA (accessed on 13 November 2018).

15. Vaske, J. Survey Research and Analysis: Applications in Parks, Recreation, and Human Dimensions; Venture Publishing: State College, PA, USA, 2008.

16. NPS. Annual Summary Report. Available online: https://irma.nps.gov/Stats/ (accessed on 13 November 2018).

17. Jager, E.; Sanche, A. Setting the stage for visitor experiences in Canada's national heritage places. George Wright Forum 2010, 27, 180-190.

18. Oppegaard, B.; Grigar, D. The interrelationships of mobile storytelling: Merging the physical and the digital at a national historic site. In The Mobile Story: Narrative Practices with Locative Technologies; Routledge: Abingdon, UK, 2014; pp. 17-33. 